\title{
Why Algae Release Volatile Organic Compounds-The Emission and Roles
}

\author{
Zhaojiang Zuo* \\ School of Forestry and Biotechnology, Zhejiang A\&F University, Hangzhou, China
}

A wide spectrum of volatile organic compounds (VOCs) are released from algae in aquatic ecosystems. Environmental factors such as light, temperature, nutrition conditions and abiotic stresses affect their emission. These VOCs can enhance the resistance to abiotic stresses, transfer information between algae, play allelopathic roles, and protect against predators. For homogeneous algae, the VOCs released from algal cells under stress conditions transfer stress information to other cells, and induce the acceptors to make a preparation for the upcoming stresses. For heterogeneous algae and aquatic macrophytes, the VOCs show allelopathic effects on the heterogeneous neighbors, which benefit to the emitter growth and competing for nutrients. In cyanobacterial VOCs, some compounds such as limonene, eucalyptol, $\beta$-cyclocitral, $\alpha$-ionone, $\beta$-ionone and geranylacetone have been detected as the allelopathic agents.

OPEN ACCESS

Edited by: Lorenzo Proia

BETA Technological Center, Spain

Reviewed by:

Ernani Pinto,

University of São Paulo, Brazil

Evgeny Kurashov,

Institute of Limnology (RAS), Russia

*Correspondence:

Zhaojiang Zuo

zuozhaojiang@126.com

Specialty section:

This article was submitted to

Aquatic Microbiology,

a section of the journal

Frontiers in Microbiology

Received: 08 January 2019

Accepted: 26 February 2019

Published: 12 March 2019

Citation:

Zuo Z (2019) Why Algae Release

Volatile Organic

Compounds - The Emission

and Roles. Front. Microbiol. 10:491.

doi: 10.3389/fmicb.2019.00491
In addition, VOCs can protect the emitters from predation by predators. It can be speculated that the emission of VOCs is critical for algae coping with the complicated and changeable aquatic ecosystems.

Keywords: allelopathy, communication, environmental factor, protection, tolerance, volatile organic compounds

\section{INTRODUCTION}

In terrestrial ecosystems, more than 30,000 volatile organic compounds (VOCs) are released from higher plant leaves, flowers and underground parts through secondary metabolism pathway (Peñuelas and Llusià, 2004). These compounds are involved in a broad array of ecological functions and are beneficial to the emitters, such as inhibiting seed germination and seedling growth of other plants (Zuo et al., 2011; Zhang et al., 2012), defensing against herbivores and pathogens (Rapisarda et al., 2012; Bee Park et al., 2013; Zhang et al., 2014), and communicating with other plants (Weir et al., 2004; Baldwin et al., 2006).

In aquatic ecosystems, algae can also release a wide spectrum of VOCs, including terpenoids, furans, sulfo compounds, alkanes, alkenes, alcohols, aldehydes, ketones, and esters (Walsh et al., 1998; Zuo et al., 2012a,b; Xu et al., 2017), which are affected by environmental factors, such as light, temperature, nutrition conditions and abiotic stresses (Bonsang et al., 2010; Zuo et al., 2012a,b; Xu et al., 2017; Ye et al., 2018). Geosmin and 2-methylisoborneol (Figure 1) released from cyanobacteria are two well-known terpenoids (Suurnäkki et al., 2015), as they can cause earthymusty odor of lake waters (Jüttner, 1995; Huang et al., 2007). Meanwhile, the compounds from the degradation of carotenoids, including $\beta$-cyclocitral, $\beta$-ionone and geranylacetone (Figure 1), also contribute to the water odor (Jüttner, 1979, 1984). It is not clear whether these odor compounds influence human health, but they dramatically impact water supplies by decreasing esthetic quality 
and increasing the costs of water treatment. In addition to causing water odor, algal VOCs serve important functions in enhancing emitters' tolerance, communicating with homogeneous algae, playing allelopathic roles in heterogeneous algae and aquatic macrophytes, and protecting against predators, which may be the true reason for algae releasing VOCs, benefiting to the survival and propagation of emitters. In this review, the emission and roles of algal VOCs are summarized.

\section{ENVIRONMENTAL FACTORS AFFECTING VOC EMISSION FROM ALGAE}

\section{Light}

Isoprene (Figure 1) is composed of 5 carbon atoms and called hemiterpene, the minimum terpenoids. Cyanobacteria, diatoms and green algae can release it with dependence on light condition (Shaw et al., 2003), e.g., the isoprene emission rate from Prochlorococcus increased with raising light intensity (Bonsang et al., 2010). When Thalassiosira weissflogii, T. pseudonana, Pleurochrysis carterae, and Rhodomonas salina were kept in different light intensity for $4 \mathrm{~h}$, isoprene was the maximum released compound with some monoterpenes which are composed of the isoprene C5 unit, and high light intensity showed promoting effect on isoprene emission (Meskhidze et al., 2015). Isoprene and monoterpenes are synthesized in plastids via methylerythritol-4-phosphate pathway (MEP) (Figure 2; Rohmer et al., 1993), and are released from algae after direct synthesis, due to no storage structure. Light promotes their emission, as the availability of energetic cofactors and $\mathrm{C}$ intermediates increases the availability of dimethylallyl pyrophosphate (DMAPP), immediate precursor of isoprene and monoterpenes in MEP (Rasulov et al., 2009; Niinemets and Sun, 2015).

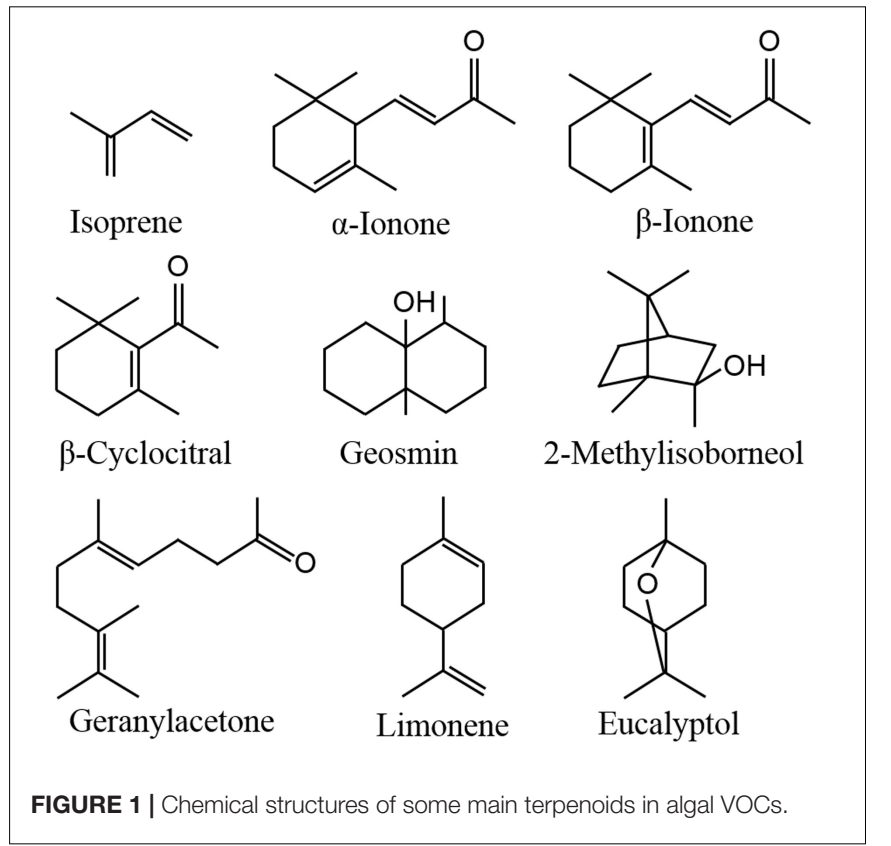

In marine algae, halogenated hydrocarbons are common compounds in their VOCs. Solieria chordalis released 9 halogenated hydrocarbons, such as $\mathrm{CH}_{3} \mathrm{I}, \mathrm{CH}_{3} \mathrm{CH}_{2} \mathrm{I}, \mathrm{CH}_{2} \mathrm{ClI}$, $\mathrm{CH}_{2} \mathrm{Br}_{2}, \mathrm{CHBrCl}_{2}, \mathrm{CHBr}_{2} \mathrm{Cl}, \mathrm{CH}_{2} \mathrm{BrI}, \mathrm{CHBr}_{3}$ and $\mathrm{CH}_{2} \mathrm{I}_{2}$, of which emission rate increased in the light but declined in the dark (Bondu et al., 2008). During a day, the highest production rate of halogenated hydrocarbons from Hypnea spinella and Falkenbergia hillebrandii was observed at mid-day (Ekdahl et al., 1998). The formation of halogenated hydrocarbons depends on the haloperoxidases that catalyze $\mathrm{H}_{2} \mathrm{O}_{2}$ oxidizing halide ions to form halogenated compounds (Ohsawa et al., 2001; Winter and Moore, 2009). $\mathrm{H}_{2} \mathrm{O}_{2}$ can be directly produced and indirectly transformed from other reactive oxygen species (ROS) in cells (Milne et al., 2009). High light intensity leads to massive ROS production and then promotes the formation and emission of halogenated hydrocarbons (Hughes and Sun, 2016).

\section{Temperature}

When Pleurosira laevis and Enteromorpha flexuosa were kept at $17^{\circ} \mathrm{C}$ and $23^{\circ} \mathrm{C}$, higher temperature promoted the emission of $\mathrm{CHCl}_{3}$ from $P$. laevis and $\mathrm{CHBr}_{3}$ from E. flexuosa (Abrahamsson et al., 2003). Heat shock increased the emission of C6 green leaf volatiles (GLVs) and carotenoid degradants from Lobaria pulmonaria, a symbiont of fungus, cyanobacterium Nostoc and green alga Dyctiochloropsis (GarcíaPlazaola et al., 2017). GLVs mainly include C6 alcohols and aldehydes, which are formed via oxidative degradation of fatty acids (Peñuelas and Llusià, 2004). $\beta$-Cyclocitral, $\alpha$-ionone (Figure 1), $\beta$-ionone and geranylacetone are typical carotenoid degradants in cyanobacteria (Jüttner, 1979, 1984; Ikawa et al., 2001). High temperature can induce the production of massive ROS in algae, which benefits to the oxidation of halide ions, fatty acids and carotenoids, leading to the formation of halogenated hydrocarbons, GLVs and carotenoid degradants.

\section{Nutrition Conditions}

In water bodies, the multiple nutrition conditions, mainly phosphorus $(\mathrm{P})$ and nitrogen $(\mathrm{N})$ forms and levels, can influence the emission of VOCs from algae. Polyphosphate (PolyP) and orthophosphate widely exist in water bodies (Nishikawa et al., 2006). When two typical algal species of cyanobacterial bloom Microcystis flos-aquae and $M$. aeruginosa were kept in the medium with $\mathrm{K}_{2} \mathrm{HPO}_{4}$, sodium pyrophosphate and sodium hexametaphosphate as the sole $\mathrm{P}$ source, they released different amount and components of VOCs, mainly including furans, sulfo compounds, terpenoids, benzenoids, hydrocarbons, aldehydes and esters. Meanwhile, non-P condition showed the maximum promoting effect on the VOC emission (Ye et al., 2018; Zuo et al., 2018b). In the field works, a negative relationship between geosmin amount and $\mathrm{P}$ concentration in reservoirs has also been found (Dzialowski et al., 2009). In aquatic ecosystem, P is considered as a limiting nutrient for algal massive growth, due to its easy precipitation as insoluble salts (Qian et al., 2011; Tekile et al., 2015). Under that condition, algae released maximum VOCs, which were beneficial to the emitters competing nutrients by inhibiting other algae (Yang et al., 2018; Zuo et al., 2018b). 


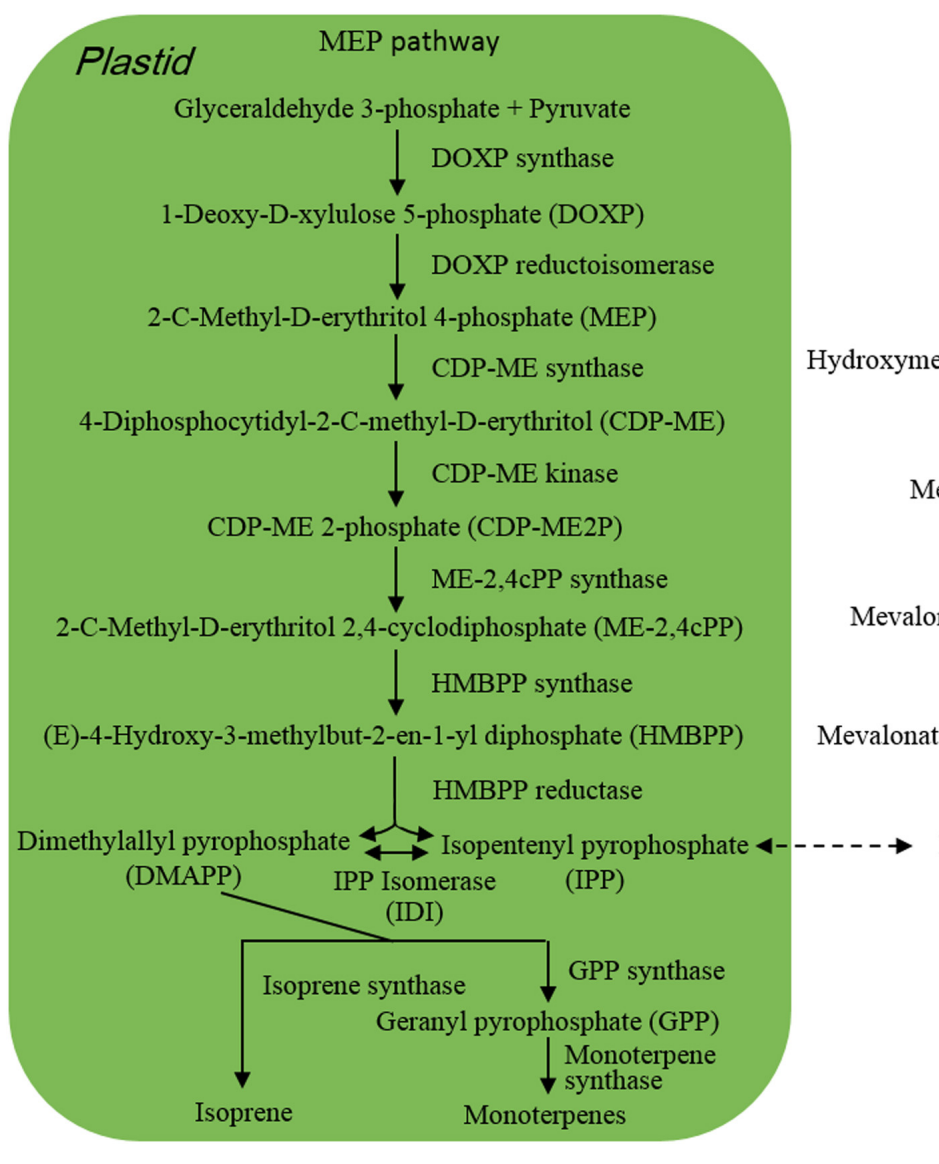

MVA pathway

Cytosol

Acetyl-CoA

$\downarrow$ acetyl-CoA acetyltransferase

Acetoacetyl-CoA

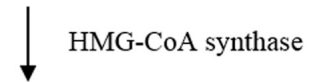

4-phosphate (MEP)

utaryl-CoA (HMG-CoA)

$\downarrow$ HMG-CoA reductase

Mevalonic acid (MVA)

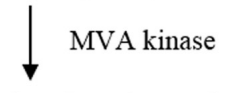

Mevalonate 5-phosphate (MVAP)

$\downarrow$ Phosphomevalonate kinase

(E)-4-Hydroxy-3-methylbut-2-en-1-yl diphosphate (HMBPP)

Mevalonate 5-pyrophosphate (MVAPP)

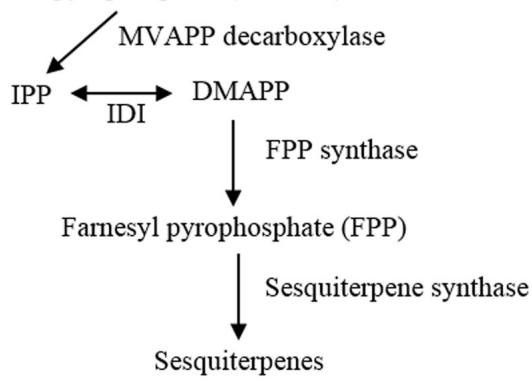

FIGURE 2 | Pathway of terpene synthesis.

When $M$. flos-aquae and $M$. aeruginosa were kept in different $\mathrm{N}$ forms such as $\mathrm{NaNO}_{3}, \mathrm{NaNO}_{2}, \mathrm{NH}_{4} \mathrm{Cl}$, urea, serine, lysine, and arginine, they released different amount and components of VOCs, and the emission amount increased with reducing $\mathrm{N}$ concentration, with the maximum emission under non-N condition (Xu et al., 2017; Zuo et al., 2018a). Similarly increased emission of alcohols and $\beta$-cyclocitral was also detected when $M$. aeruginosa cells exhausted nitrate $\mathrm{N}$ nutrient after 35 days (Hasegawa et al., 2012). Under non$\mathrm{N}$ condition, $M$. aeruginosa cells significantly up-regulated the expression of 4 genes which encoded pyruvate kinase, malic enzyme, phosphotransacetylase and aspartate aminotransferase, respectively (Zuo et al., 2018a). Pyruvate and acetyl-CoA are immediate precursors of isoprene and monoterpenes in MEP and sesquiterpenes in mevalonate pathway (MVA) (Figure 2), respectively. Pyruvate kinase catalyzes the formation of pyruvate by transferring a phosphate group from phosphoenolpyruvate to adenosine diphosphate (ADP) (Zhang et al., 2017). Malic enzyme and phosphotransacetylase are involved in the formation of acetyl-CoA (Kyrtopoulos and Satchell, 1972; Ikaran et al., 2015). Benzenoids and phenylpropanoids are considered as the second largest class of VOCs after terpenoids (Dudareva et al., 2013; Sun et al., 2016), which are mainly derived from phenylalanine. Aspartate aminotransferase functioned in the synthesis of phenylalanine in the last step of shikimate pathway (Maeda et al., 2011). Non-N condition induced the expression of genes that were involved in the formation of terpenoid and benzenoid precursors and promoted VOC emission (Zuo et al., 2018a).

\section{Abiotic Stresses}

Chlamydomonas reinhardtii is a model material for algal research, and released plenty of VOCs, including alkanes, alkenes, terpenoids, alcohols, aldehydes, ketones, and esters. Their emission amount and components increased when the cells were stressed by acetic acid, $\mathrm{NaCl}$ and $\mathrm{Na}_{2} \mathrm{CO}_{3}$ (Zuo et al., 2012a,b, 2015). Meanwhile, GLVs were induced to release under acetic acid and $\mathrm{NaCl}$ stresses, but not under $\mathrm{Na}_{2} \mathrm{CO}_{3}$ stress (Zuo et al., 2012a,b). Similarly, $\mathrm{NaNO}_{3}$ stress promoted the emission of terpenoids, sulfocompounds, benzenoids, aldehydes and esters from M. flos-aquae and M. aeruginosa cells (Gan et al., 2015). Under salt stress, Solieria chordalis and Gymnogongrus antarcticus increased the emission of halogenated hydrocarbons, which may result from the increased ROS under the stress (Laturnus et al., 2000; Bondu et al., 2008).

Although aquatic environment is relative stable compared to terrestrial environment, algae are easily influenced by environmental factors, due to their difficult movement and fast migration by water flow. They adjust VOC synthesis and increase 
the emission under abiotic stresses, such as high light, warmer temperature, nutrient deficiency, increased salinity and acidity. These VOCs perform important ecological functions (Watson, 2003; Fink, 2007; Zuo et al., 2012a, 2018b), which should be survival strategies for the emitters and their population.

\section{ECOLOGICAL FUNCTIONS OF ALGAL VOCS}

\section{Lowering Oxidative Stress in Algae}

Abiotic stresses induce the production of massive ROS in algal cells, indicating that algae not only suffer the direct abiotic stresses but also the indirect oxidative stress. Although ROS are important signaling molecule, their massive accumulation can damage the photosynthetic apparatus, cell membranes, proteins and DNA (Affenzeller et al., 2009; Tartoura and Youssef, 2011; Zuo et al., 2014; He et al., 2015), and even induce programmed cell death (PCD) (Affenzeller et al., 2009; Chen et al., 2019). In higher plants, their VOCs especially isoprene and monoterpenes have been recognized as the antioxidant agents to scavenge ROS and protect cell membrane and photosynthetic apparatus under several abiotic stresses, such as high temperature, drought, salinity, ozone, etc. (Vickers et al., 2009; Schaub et al., 2010; Velikova et al., 2011; Zuo et al., 2017). Isoprene and monoterpenes were released from several algae under abiotic stresses (Zuo et al., 2012a,b; Meskhidze et al., 2015; Xu et al., 2017), indicating that they might play antioxidative roles under stresses. pH 5.0 acetic acid induced $C$. reinhardtii cells to undergo $\mathrm{PCD}$, and $\mathrm{O}_{2-}$ and $\mathrm{H}_{2} \mathrm{O}_{2}$ rapidly accumulated to high levels in the cells at the beginning of the PCD and reduced during the process. During the ROS decrease, antioxidant enzymes did not contribute too much in scavenging ROS, as their activities declined quickly and even disappeared. However, VOCs may play important roles in scavenging or adjusting ROS levels, due to the dramatic increase of oxygenated compounds, including ketones, esters and aldehydes (Zuo et al., 2015). In algae, the massively produced ROS may be used to oxidize halide ions, fatty acids and carotenoids to lower oxidative damage, with emission of halogenated hydrocarbons, GLVs and carotenoid degradants (Jüttner, 1984; Ohsawa et al., 2001; Peñuelas and Llusià, 2004; Winter and Moore, 2009). It can be speculated that the production and emission of VOCs are beneficial to algal cells resisting ROS under abiotic stresses.

\section{Inducing Defense in Homogeneous Algae}

When healthy $C$. reinhardtii cells were exposed to the VOCs from $C$. reinhardtii undergoing $\mathrm{PCD}$, their normal growth declined but the activities of antioxidant enzymes increased (Zuo et al., 2012a). Similar effects were also found when healthy C. reinhardtii cells were exposed to the VOCs from the cells under $\mathrm{NaCl}$ and $\mathrm{NaCO}_{3}$ stresses (Zuo et al., 2012b). C. reinhardtii released $\mathrm{NO}$ and ethylene during PCD induced by wasp venom, and the two volatile molecules were considered as the information compounds that transferred information for other healthy $C$. reinhardtii cells, as the healthy cells treated with the solution that underwent PCD were not induced PCD by wasp venom (Yordanova et al., 2010). These results indicate that stress-induced VOCs are information agents that transfer message to other homogeneous cells and induce them to make a preparation for the upcoming stresses. This message transfer has been well studied between higher plants, which is called "cross-talk trees" and may derive from the primitive organism algae (Weir et al., 2004; Baldwin et al., 2006; Kessler et al., 2006). The information transfer mechanism serves the same function in algae and plants, which can avoid them from the sustaining defense consumption and be beneficial to the growth and propagation of the population.

\section{Allelopathic Effects on Other Heterogeneous Algae and Aquatic Macrophytes}

In eutrophicated water, cyanobacteria massively grow and dominate the water bodies with reduction and even disappearance of other algae and aquatic macrophytes. It is well known that algal toxins from cyanobacteria play an important allelopathic role during the process (Suikkanen et al., 2004; Fink, 2007; Li and Li, 2012). Similarly, the VOCs from cyanobacteria have also been found as the allelopathic agents for other algae (Watson, 2003). When Chlorella vulgaris was exposed to the VOCs from $M$. flos-aquae under non-N condition, remarkable decreases were detected in the cell growth, photosynthetic pigment content and photosynthetic abilities (Xu et al., 2017). Similar results were also found in C. reinhardtii cells in exposure of the VOCs from $M$. flos-aquae and $M$. aeruginosa under non-P condition (Yang et al., 2018; Zuo et al., 2018b). For aquatic macrophytes, there are very limited reports about their reduction which results from cyanobacterial VOC allelopathy. When Lactuca sativa seeds were exposed to dimethyl disulfide, their germination was inhibited markedly (Gómez-Tenorio et al., 2015). In addition, C. vulgaris VOCs showed inhibitory effects on the $\alpha$-amylase activity and coleoptile growth of barley (Abdel-Baky et al., 2002), indicating that algal VOCs might also have allelopathic effects on macrophytes. In eutrophicated water, the massive growth of cyanobacteria will compete with nutrients with other algae and aquatic macrophytes, which easily result in the lack of nutrients, especially $\mathrm{N}$ and $\mathrm{P}$. This lack can induce abundant VOC emissions from cyanobacteria to keep the emitters' competitive advantage for nutrients by inhibiting other competitors.

Among the abundance of VOCs from Microcystis, limonene and eucalyptol (Figure 1) showed inhibitory effects on C. vulgaris and $C$. reinhardtii cell growth by inducing photosynthetic pigment degradation and declining photosynthetic abilities (Zhao et al., 2016; Zhou et al., 2016). $\beta$-Cyclocitral, $\alpha$-ionone, $\beta$-ionone and geranylacetone were also the main compounds in Microcystis VOCs, which showed inhibitory effects on C. pyrenoidosa cell growth (Ikawa et al., 2001). Meanwhile, $\beta$-cyclocitral of $0.1-0.5 \mathrm{mg} \cdot \mathrm{ml}^{-1}$ can cause cell rupture of Nitzschia palea (Chang et al., 2011). Moreover, high concentration $\beta$-cyclocitral even impact the growth of 
Microcystis, by causing lysis (Ozaki et al., 2008). These results suggest that these compounds may be the main allelopathic agents in cyanobacterial VOCs, but the agents with high concentration may be detrimental to the emitters.

\section{Protecting Algae Against Predators}

Algae are the primary producers in aquatic ecosystems, which are preyed by predators as food. VOCs play important roles in protecting algae from predation (Fink, 2007). When diatom cells were damaged, they released polyunsaturated eicosapentaenoic acid which was toxic for crustacean herbivores (Jüttner, 2001). Meanwhile, diatoms can release polyunsaturated aldehydes to repel herbivorous zooplankton (Jüttner, 2005) and inhibit sea urchin laying eggs (Miralto et al., 1999). After damage, Thalassiosira rotula released 2,4-decadienal and 2,4,7-decatrienal which were converted from free fatty acids by lipoxygenases to defense (Pohnert, 2002). Compared to Dictyopteris membranacea with releasing C11 sulfocompounds, Ampithoe longimana tended to feed Dictyopteris hoytii without releasing the compounds (Schnitzler et al., 2001). In the treatments with $\beta$-cyclocitral and 2,4,7-decatrienal, the swimming velocity of Daphnia magna increased significantly (Watson et al., 2007; Jüttner et al., 2010), indicating that the two compounds can protect algal cells by repelling the predators. Meanwhile, polyunsaturated fatty acids showed inhibitory effects on D. magna laying eggs (MartinCreuzburg and von Elert, 2009). Although sterols produced from algae were not detected in the VOCs, they impacted the growth and reproduction of Daphnia (Martin-Creuzburg and von Elert, 2004; Martin-Creuzburg et al., 2014) and sexual development of sea scallop (Wang and Croll, 2004) due to their roles as hormones, indicating these compounds should also be protective agents. These protective mechanisms are also reserved in higher plants to repel insects or impact their development with more compounds (Rapisarda et al., 2012; Bee Park et al., 2013; Zhang et al., 2014), which are crucial to algae and plants protecting themselves against predators.

\section{REFERENCES}

Abdel-Baky, H. H., Shallan, M. A., El- Baroty, G., and El-Baz, F. K. (2002). Volatile compounds of the microalga Chlorella vulgaris and their phytotoxic effect. Pak. J. Biol. Sci. 5, 61-65. doi: 10.3923/pjbs.2002.61.65

Abrahamsson, K., Choo, K. S., Pedersén, M., Johansson, G., and Snoeijs, P. (2003). Effects of temperature on the production of hydrogen peroxide and volatile halocarbons by brackish-water algae. Phytochemistry 64, 725-734. doi: 10.1016/ S0031-9422(03)00419-9

Affenzeller, M. J., Darehshouri, A., Andosch, A., Lütz, C., and Meindl, U. L. (2009). Salt stress-induced cell death in the unicellular green alga Micrasterias denticulate. J. Exp. Bot. 60, 939-954. doi: 10.1093/jxb/ ern348

Baldwin, I. T., Halitschke, R., Paschold, A., Von Dahl, C. C., and Preston, C. A. (2006). Volatile signaling in plant-plant interactions: "talking trees" in the genomics era. Science 311, 812-815. doi: 10.1126/science.111 8446

Bee Park, H., Lee, B., Kloepper, J. W., and Ryu, C. M. (2013). One shot-two pathogens blocked: exposure of Arabidopsis to hexadecane, a long chain volatile organic compound, confers induced resistance against both Pectobacterium carotovorum and Pseudomonas syringae. Plant Signal. Behav. 8:e24619. doi: $10.4161 /$ psb.24619

\section{PROSPECTION}

In aquatic ecosystems, algae release an abundance of VOCs to increase their tolerance to abiotic stresses, transfer stress information to homogeneous algae to induce defense, play allelopathic roles on heterogeneous algae and aquatic macrophytes for competing nutrients, or protect against predators. The functions of VOCs in algae are very similar to that in higher plants. However, the studies about algal VOCs, especially their roles, are still in the primary stage. For emitters, how do they release the VOCs to response different environmental conditions? For acceptors, it is important for them to identify and sense the signaling molecule and make a correct response further. Algal VOCs are a blend of compounds. Which are the exact information agents among them? What is the exact information for each agent? These questions should be answered in future studies to uncover the VOC communication by using molecular biology and technology. Undoubtedly, the emission of VOCs from algae is critical and beneficial to the survival and reproduction of emitters and their population in response to the complicated and changeable aquatic ecosystems.

\section{AUTHOR CONTRIBUTIONS}

The author confirms being the sole contributor of this work and has approved it for publication.

\section{FUNDING}

This research was supported by the National Natural Science Foundation of China (Nos. 31870585 and 31300364), the Basic Public Welfare Research Project of Zhejiang Province (No. LGN19C150006), the Natural Science Foundation of Zhejiang Province (No. LY17C160004).

Bondu, S., Cocquempot, B., Deslandes, E., and Morin, P. (2008). Effects of salt and light stress on the release of volatile halogenated organic compounds by Solieria chordalis: a laboratory incubation study. Bot. Mar. 51, 485-492. doi: 10.1515/BOT.2008.056

Bonsang, B., Gros, V., Peeken, I., Yassaa, N., Bluhm, K., and Zoellner, E. (2010). Isoprene emission from phytoplankton monocultures: the relationship with chlorophyll-a, cell volume and carbon content. Environ. Chem. 7, 554-563. doi: 10.1071/EN09156

Chang, D. W., Hsieh, M. L., Chen, Y. M., Lin, T. F., and Chang, J. S. (2011). Kinetics of cell lysis for Microcystis aeruginosa and Nitzschia palea in the exposure to $\beta$-cyclocitral. J. Hazard. Mater. 185, 1214-1220. doi: 10.1016/j.jhazmat.2010. 10.033

Chen, Y., Weng, Y., Zhou, M., Meng, Y., Liu, J., Yang, L., et al. (2019). Linalool- and $\alpha$-terpineol-induced programmed cell death in Chlamydomonas reinhardtii. Ecotoxicol. Environ. Saf. 167, 435-440. doi: 10.1016/j.ecoenv.2018.10.062

Dudareva, N., Klempien, A., Muhlemann, J. K., and Kaplan, I. (2013). Biosynthesis, function and metabolic engineering of plant volatile organic compounds. New Phytol. 198, 16-32. doi: 10.1111/nph.12145

Dzialowski, A. R., Smith, V. H., Huggins, D. G., deNoyelles, F., Lim, N.-C., Baker, D. S., et al. (2009). Development of predictive models for geosmin-related taste and odor in Kansas, USA, drinking water reservoirs. Water Res. 43, 2829-2840. doi: 10.1016/j.watres.2009.04.001 
Ekdahl, A., Pedersén, M., and Abrahamsson, K. (1998). A study of the diurnal variation of biogenic volatile halocarbons. Mar. Chem. 63, 1-8. doi: 10.1016/ S0304-4203(98)00047-4

Fink, P. (2007). Ecological functions of volatile organic compounds in aquatic systems. Mar. Freshw. Behav. Phys. 40, 155-168. doi: 10.1080/ 10236240701602218

Gan, L., Xu, Q., Yang, W., Zhao, J., Zhou, L., and Zuo, Z. (2015). The effects of NaNO3 stress on the release of VOCs from two Microcystis. Acta Hydrobiol. Sin. 39, 782-788.

García-Plazaola, J. I., Portillo-Estrada, M., Fernández-Marín, B., Kännaste, A., and Niinemets, Ü. (2017). Emissions of carotenoid cleavage products upon heat shock and mechanical wounding from a foliose lichen. Environ. Exp. Bot. 133, 87-97. doi: 10.1016/j.envexpbot.2016.10.004

Gómez-Tenorio, M. A., Zanón, M. J., de Cara, M., Lupión, B., and Tello, J. C. (2015). Efficacy of dimethyl disulfide (DMDS) against Meloidogyne sp. and three formae speciales of Fusarium oxysporum under controlled conditions. Crop Prot. 78, 263-269. doi: 10.1016/j.cropro.2015.09.013

Hasegawa, M., Nishizawa, A., Tsuji, K., Kimura, S., and Harada, K. (2012). Volatile organic compounds derived from 2-keto-acid decarboxylase in Microcystis aeruginosa. Microbes Environ. 27, 525-528. doi: 10.1264/jsme2.ME12099

He, L. L., Wang, X., Wu, X. X., Wang, Y. X., Kong, Y. M., Wang, X., et al. (2015). Protein damage and reactive oxygen species generation induced by the synergistic effects of ultrasound and methylene blue. Spectrochim. Acta A Mol. Biomol. Spectrosc. 134, 361-366. doi: 10.1016/j.saa.2014.06.121

Huang, W. J., Lai, C. H., and Cheng, Y. L. (2007). Evaluation of extracellular products and mutagenicity in cyanobacteria cultures separated from a eutrophic reservoir. Sci. Total Environ. 377, 214-223. doi: 10.1016/j.scitotenv. 2007.01.075

Hughes, C., and Sun, S. (2016). Light and brominating activity in two species of marine diatom. Mar. Chem. 181, 1-9. doi: 10.1016/j.marchem.2016. 02.003

Ikaran, Z., Suárez-Alvarez, S., Urreta, I., and Castañón, S. (2015). The effect of nitrogen limitation on the physiology and metabolism of Chlorella vulgaris var L3. Algal Res. 10, 134-144. doi: 10.1016/j.algal.2015.04.023

Ikawa, M., Sasner, J. J., and Haney, J. F. (2001). Activity of cyanobacterial and algal odor compounds found in lake waters on green alga Chlorella pyrenoidosa growth. Hydrobiologia 443, 19-22. doi: 10.1023/A:1017535801766

Jüttner, F. (1979). Nor-carotenoids as the major volatile excretion products of Cyanidium. Z. Naturforsch. 34c, 186-191. doi: 10.1515/znc-1979-3-405

Jüttner, F. (1984). Characterization of Microcystis strains by alkyl sulfides and $\beta$-cyclocitral. Z. Naturforsch. 39c, 867-871. doi: 10.1515/znc-1984-9-1002

Jüttner, F. (1995). Physiology and biochemistry of odorous compounds from freshwater cyanobacteria and algae. Water Sci. Technol. 31, 69-78. doi: 10.2166/wst. 1995.0405

Jüttner, F. (2001). Liberation of 5,8,11,14,17-eicosapentaenoic acid and other polyunsaturated fatty acids from lipids as a grazer defense reaction in epilithic diatom biofilms. J. Phycol. 37, 744-755. doi: 10.1046/j.1529-8817.2001.00130.x

Jüttner, F. (2005). Evidence that polyunsaturated aldehydes of diatoms are repellents for pelagic crustacean grazers. Aquat. Ecol. 39, 271-282. doi: 10.1007/ s10452-005-3419-9

Jüttner, F., Watson, S. B., von Elert, E., and Köster, O. (2010). $\beta$-Cyclocitral, a grazer defence signal unique to the cyanobacterium Microcystis. J. Chem. Ecol. 36, 1387-1397. doi: 10.1007/s10886-010-9877-0

Kessler, A., Halitschke, R., Diezel, C., and Baldwin, I. T. (2006). Priming of plant defense responses in nature by airborne signaling between Artemisia tridentata and Nicotiana attenuate. Oecologia 148, 280-292. doi: 10.1007/s00442-0060365-8

Kyrtopoulos, S. A., and Satchell, D. P. N. (1972). Kinetic studies with phosphotransacetylase: III. The acylation of phosphate ions by acetyl coenzyme A. Biochim. Biophys. Acta 276, 376-382. doi: 10.1016/0005-2744(72)90 997-7

Laturnus, F., Giese, B., Wiencke, C., and Adams, F. C. (2000). Low molecular weight organoiodine and organobromine compounds released by polar macroalgae-the influence of abiotic factors. Fresenius J. Anal. Chem. 368, 297-302. doi: 10.1007/s002160000491

Li, Y., and Li, D. (2012). Competition between toxic Microcystis aeruginosa and nontoxic Microcystis wesenbergii with Anabaena PCC7120. J. Appl. Phycol. 24, 69-78. doi: 10.1007/s10811-010-9648-x
Maeda, H., Yoo, H., and Dudareva, N. (2011). Prephenate aminotransferase directs plant phenylalanine biosynthesis via arogenate. Nat. Chem. Biol. 7, 19-21. doi: $10.1038 /$ nchembio. 485

Martin-Creuzburg, D., Oexle, S., and Wacker, A. (2014). Thresholds for sterollimited growth of Daphnia magna: a comparative approach using 10 different sterols. J. Chem. Ecol. 40, 1039-1050. doi: 10.1007/s10886-014-0486-1

Martin-Creuzburg, D., and von Elert, E. (2004). Impact of 10 dietary sterols on growth and reproduction of Daphnia galeata. J. Chem. Ecol. 30, 483-500. doi: 10.1023/B:JOEC.0000018624.94689.95

Martin-Creuzburg, D., and von Elert, E. (2009). Good food versus bad food: the role of sterols and polyunsaturated fatty acids in determining growth and reproduction of Daphnia magna. Aquat. Ecol. 43, 943-950. doi: 10.1007/ s10452-009-9239-6

Meskhidze, N., Sabolis, A., Reed, R., and Kamykowski, D. (2015). Quantifying environmental stress-induced emissions of algal isoprene and monoterpenes using laboratory measurements. Biogeosciences 12, 637-651. doi: 10.5194/bg12-637-2015

Milne, A., Davey, M. S., Worsford, P. S., Achterberg, E. P., and Taylor, A. R. (2009). Real-time detection of reactive oxygen species generation by marine phytoplankton using flow injection-chemiluminescence. Limnol. Oceanogr. Methods 7, 706-715. doi: 10.4319/lom.2009.7.706

Miralto, A., Barone, G., Romano, G., Poulet, S. A., Ianora, A., Russo, G. L., et al. (1999). The insidious effect of diatoms on copepod reproduction. Nature 402, 173-176. doi: 10.1038/46023

Niinemets, Ü., and Sun, Z. (2015). How light, temperature, and measurement and growth [CO2] interactively control isoprene emission in hybrid aspen. J. Exp. Bot. 66, 841-851. doi: 10.1093/jxb/eru443

Nishikawa, K., Machida, H., Yamakoshi, Y., Ohtomo, R., Saito, K., Saito, M., et al. (2006). Polyphosphate metabolism in an acidophilic alga Chlamydomonas acidophila KT-1 (Chlorophyta) under phosphate stress. Plant Sci. 170, 307-313. doi: 10.1016/j.plantsci.2005.08.025

Ohsawa, N., Ogata, Y., Okada, N., and Itoh, N. (2001). Physiological function of bromoperoxidase in the red marine alga, Corallina pilulifera production of bromoform as an allelochemical and the simultaneous elimination of hydrogen peroxide. Phytochemistry 58, 683-692. doi: 10.1016/S0031-9422(01)00259-X

Ozaki, K., Ohta, A., Iwata, C., Horikawa, A., Tsuji, K., Ito, E., et al. (2008). Lysis of cyanobacteria with volatile organic compounds. Chemosphere 71, 1531-1538. doi: 10.1016/j.chemosphere.2007.11.052

Peñuelas, J., and Llusià, J. (2004). Plant VOC emissions: making use of the unavoidable. Trends Ecol. Evol. 19, 402-404. doi: 10.1016/j.tree.2004.06.002

Pohnert, G. (2002). Phospholipase A2 activity triggers the wound activated chemical defense in the diatom Thalassiosira rotula. Plant Physiol. 129, 103-111. doi: 10.1104/pp.010974

Qian, Z. L., Wang, H. J., and Sun, J. Q. (2011). The hindcast of winter and spring Arctic and Antarctic Oscillation with the coupled climate models. Acta Meteorol. Sin. 25, 340-354. doi: 10.1007/s13351-011-0309-z

Rapisarda, T., Mereu, A., Cannas, A., Belvedere, G., Licitra, G., and Carpino, S. (2012). Volatile organic compounds and palatability of concentrates fed to lambs and ewes. Small Rumin. Res. 103, 120-132. doi: 10.1016/j.smallrumres. 2011.08.011

Rasulov, B., Copolovici, L., Laisk, A., and Niinemets, Ü. (2009). Postillumination isoprene emission: in vivo measurements of dimethylallyldiphosphate pool size and isoprene synthase kinetics in aspen leaves. Plant Physiol. 149, 1609-1618. doi: $10.1104 /$ pp.108.133512

Rohmer, M., Knani, M., Simonin, P., Sutter, B., and Sahm, H. (1993). Isoprenoid biosynthesis in bacteria: a novel pathway for the early steps leading to isopentenyl diphosphate. Biochem. J. 295, 517-524. doi: 10.1042/bj2950517

Schaub, A., Blande, J. D., Graus, M., Oksanen, E., Holopainen, J. K., and Hansel, A. (2010). Realtime monitoring of herbivore induced volatile emissions in the field. Physiol. Plant. 138, 123-133. doi: 10.1111/j.1399-3054.2009.01322.x

Schnitzler, I., Pohnert, G., Hay, M. E., and Boland, W. (2001). Chemical defense of brown algae (Dictyopteris spp.) against the herbivorous amphipod Ampithoe longimana. Oecologia 126, 515-521. doi: 10.1007/s004420000546

Shaw, S. L., Chisholm, S. W., and Prinn, R. (2003). Isoprene production by Prochlorococcus, a marine cyanobacterium, and other phytoplankton. Mar. Chem. 80, 227-245. doi: 10.1016/S0304-4203(02)00101-9

Suikkanen, S., Fistarol, G. O., and Granèli, E. (2004). Allelopathic effects of the Baltic cyanobacteria Nodularia spumigena, Aphanizomenon flos-aquae and 
Anabaena lemmermannii on algal monocultures. J. Exp. Mar. Biol. Ecol. 308, 85-101. doi: 10.1016/j.jembe.2004.02.012

Sun, P., Schuurink, R. C., Caissard, J. C., Hugueney, P., and Baudino, S. (2016). My way: noncanonical biosynthesis pathways for plant volatiles. Trends Plant Sci. 21, 884-894. doi: 10.1016/j.tplants.2016.07.007

Suurnäkki, S., Gomez-Saez, G. V., Rantala-Ylinen, A., Jokela, J., Fewer, D. P., and Sivonen, K. (2015). Identification of geosmin and 2-methylisoborneol in cyanobacteria and molecular detection methods for the producers of these compounds. Water Res. 68, 56-66. doi: 10.1016/j.watres.2014.09.037

Tartoura, K. A. H., and Youssef, S. A. (2011). Stimulation of ROS-scavenging systems in squash (Cucurbita pepo L.) plants by compost supplementation under normal and low temperature conditions. Sci. Hortic. 130, 862-868. doi: 10.1016/j.scienta.2011.08.015

Tekile, A., Kim, I., and Kim, J. (2015). Mini-review on river eutrophication and bottom improvement techniques, with special emphasis on the Nakdong River. J. Environ. Sci. 30, 113-121. doi: 10.1016/j.jes.2014.10.014

Velikova, V., Várkonyi, Z., Szabó, M., Maslenkova, L., Nogues, I., Kovács, L., et al. (2011). Increased thermos stability of thylakoid membranes in isoprene emitting leaves probed with three biophysical techniques. Plant Physiol. 157, 905-916. doi: 10.1104/pp.111.182519

Vickers, C. E., Possell, M., Cojocariu, C. I., Velikova, V. B., Laothawornkitkul, J., Ryan, A., et al. (2009). Isoprene synthesis protects transgenic tobacco plants from oxidative stress. Plant Cell Environ. 32, 520-531. doi: 10.1111/j.1365-3040. 2009.01946.x

Walsh, K., Jones, G. J., and Dunstan, R. H. (1998). Effect of high irradiance and iron on volatile odour compounds in the cyanobacterium Microcystis aeruginosa. Phytochemistry 49, 1227-1239. doi: 10.1016/S0031-9422(97)00943-6

Wang, C., and Croll, R. P. (2004). Effects of sex steroids on gonadal development and gender determination in the sea scallop, Placopecten magellanicus. Aquaculture 238, 483-498. doi: 10.1016/j.aquaculture.2004.05.024

Watson, S. (2003). Cyanobacterial and eukaryotic algal odour compounds: signals or by-products? A review of their biological activity. Phycologia 42, 332-350. doi: 10.2216/i0031-8884-42-4-332.1

Watson, S. B., Jüttner, F., and Köster, O. (2007). Daphnia behavioural responses to taste and odour compounds: ecological significance and application as an inline treatment plant monitoring tool. Water Sci. Technol. 55, 23-31. doi: 10.2166/wst.2007.158

Weir, T. L., Park, S., and Vivanco, J. M. (2004). Biochemical and physiological mechanisms mediated by allelochemicals. Curr. Opin. Plant Biol. 7, 472-479. doi: $10.1016 /$ j.pbi.2004.05.007

Winter, J. M., and Moore, B. S. (2009). Exploring the chemistry and biology of vanadium-dependent haloperoxidases. J. Biol. Chem. 284, 18577-18581. doi: 10.1074/jbc.R109.001602

Xu, Q., Yang, L., Yang, W., Bai, Y., Hou, P., Zhao, J., et al. (2017). Volatile organic compounds released from Microcystis flos-aquae under nitrogen sources and their toxic effects on Chlorella vulgaris. Ecotoxicol. Environ. Saf. 135, 191-200. doi: 10.1016/j.ecoenv.2016.09.027

Yang, W., Zhao, J., Xu, Q., Zhou, L., Gan, L., and Zuo, Z. (2018). Phosphorus deficiency inducing volatile organic compounds from Microcystis aeruginosa and their effects on Chlamydomonas reinhardtii. J. Lake Sci. 30, 449-457. doi: $10.18307 / 2018.0216$

Ye, C., Yang, Y., Xu, Q., Ying, B., Zhang, M., Gao, B., et al. (2018). Volatile organic compound emissions from Microcystis aeruginosa under different phosphorus sources and concentrations. Phycol. Res. 66, 15-22. doi: 10.1111/pre.12201

Yordanova, Z. P., Iakimova, E. T., Cristescu, S. M., Harren, F. J. M., Kapchina-Toteva, V. M., and Woltering, E. J. (2010). Involvement of ethylene and nitric oxide in cell death in mastoparan-treated unicellular alga Chlamydomonas reinhardtii. Cell Biol. Int. 34, 301-308. doi: 10.1042/CBI2009 0138
Zhang, R., Zhang, W., Zuo, Z., Li, R., Wu, J., and Gao, Y. (2014). Inhibition effects of volatile organic compounds from Artemisia frigida Willd. On the pasture grass intake by lambs. Small Rumin. Res. 121, 248-254. doi: 10.1016/ j.smallrumres.2014.06.001

Zhang, R. M., Zuo, Z. J., Gao, P. J., Hou, P., Wen, G. S., and Gao, Y. (2012). Allelopathic effects of VOCs of Artemisia frigida Willd. On the regeneration of pasture grasses in Inner Mongolia. J. Arid Environ. 87, 212-218. doi: 10.1016/j. jaridenv.2012.04.008

Zhang, X., Lai, L., Xu, G., Zhang, X., Shi, J., and Xu, Z. (2017). Effects of pyruvate kinase on the growth of Corynebacterium glutamicum and L-serine accumulation. Process Biochem. 55, 32-40. doi: 10.1016/j.procbio.2017. 01.028

Zhao, J., Yang, L., Zhou, L., Bai, Y., Wang, B., Hou, P., et al. (2016). Inhibitory effects of eucalyptol and limonene on the photosynthetic abilities in Chlorella vulgaris (Chlorophyceae). Phycologia 55, 696-702. doi: 10.2216/1 6-38.1

Zhou, L., Zhao, J., Xu, Q., Yang, W., and Zuo, Z. (2016). Effects of eucalyptol and limonene on the photosynthetic abilities in Chlamydomonas reinhardtii. Acta Hydrobiol. Sin. 40, 294-300. doi: 10.1007/s10653-017-0055-y

Zuo, Z., Chen, Z., Zhu, Y., Bai, Y., and Wang, Y. (2014). Effects of $\mathrm{NaCl}$ and $\mathrm{Na} 2 \mathrm{CO} 3$ stresses on photosynthetic ability of Chlamydomonas reinhardtii. Biologia 69, 1314-1322. doi: 10.2478/s11756-014-0437-x

Zuo, Z., Chen, Z., Zhu, Y., Bai, Y., and Wang, Y. (2015). Reactive oxygen species contribute to the release of volatile organic compounds from Chlamydomonas reinhardtii during programmed cell death. Phycol. Res. 63, 37-42. doi: 10.1111/ pre. 12071

Zuo, Z., Wang, B., Ying, B., Zhou, L., and Zhang, R. (2017). Monoterpene emissions contribute to thermotolerance in Cinnamomum camphora. Trees 31, 1759-1771. doi: 10.1007/s00468-017-1582-y

Zuo, Z., Yang, L., Chen, S., Ye, C., Han, Y., Wang, S., et al. (2018a). Effects of nitrogen nutrients on the volatile organic compound emissions from Microcystis aeruginosa. Ecotoxicol. Environ. Saf. 161, 214-220. doi: 10.1016/j. ecoenv.2018.05.095

Zuo, Z., Yang, Y., Xu, Q., Yang, W., Zhao, J., and Zhou, L. (2018b). Effects of phosphorus sources on volatile organic compound emissions from Microcystis flos-aquae and their toxic effects on Chlamydomonas reinhardtii. Environ. Geochem. Health 40, 1283-1298. doi: 10.1007/s10653-017-0055-y

Zuo, Z., Zhang, R., Gao, P., Wen, G., Hou, P., and Gao, Y. (2011). Allelopathic effects of Artemisia frigida Willd. On growth of pasture grasses in Inner Mongolia, China. Biochem. Syst. Ecol. 39, 377-383. doi: 10.1016/j.bse.2011. 05.010

Zuo, Z., Zhu, Y., Bai, Y., and Wang, Y. (2012a). Acetic acid-induced programmed cell death and release of volatile organic compounds in Chlamydomonas reinhardtii. Plant Physiol. Biochem. 51, 175-184. doi: 10.1016/j.plaphy.2011.11.003

Zuo, Z., Zhu, Y., Bai, Y., and Wang, Y. (2012b). Volatile communication between Chlamydomonas reinhardtii cells under salt stress. Biochem. Syst. Ecol. 40, 19-24. doi: 10.1016/j.bse.2011.09.007

Conflict of Interest Statement: The author declares that the research was conducted in the absence of any commercial or financial relationships that could be construed as a potential conflict of interest.

Copyright (c) 2019 Zuo. This is an open-access article distributed under the terms of the Creative Commons Attribution License (CC BY). The use, distribution or reproduction in other forums is permitted, provided the original author(s) and the copyright owner(s) are credited and that the original publication in this journal is cited, in accordance with accepted academic practice. No use, distribution or reproduction is permitted which does not comply with these terms. 